Hossein Askari, Review of the above book, Iranian Studies, Vol. XVII, No. 2-3, Spring-Summer 1984, pp. 318-19.

Homa Katouzian, "The Aridisolabic Society, A Model of Long Term Social and Economic Development in Iran," The International Journal of Middle Eastern Studies, 15 (1983), pp. 259-281.

\title{
Homa Katouzian
}

[Homa Katouzian is Senior Lecturer of Economics at the University of Kent at Canterbury.]

To the Editors:

Mr. Rajaee has written a superficial and silly review of my book, Paved with Good Intentions: The American Experience and Iran. First of all, he plays with the title-and his apparent reading of only the first ten pages of the book--to imply that I argue the U.S. interest in Iran was based on American altruism.

Whole chapters of the book are spent discussing the strategic and economic basis of U.S. policy over several decades. The U.S. "main objective" in the Third World "was the prevention of the spread of Soviet influence" (p. 56); in the 1950s "Washington's commitment continued to be essentially limited to Iran's protection from direct Soviet attack" (p. 91) but by the 1960s U.S. policy sought to use Iran "as the key pillar of support for American interests" in the Gulf, making it "into a regionally dominant power" and building it up militarily (pp. 124-25). I go into great detail on these geostrategic policies.

Outright falsifications obviously do not bother $\mathrm{Mr}$. Rajaee either. He claims I do not mention the post-1953 U.S. oil company interest in Iran but it is clearly set forth on page 95. He claims that I describe Ayatollah Kashani as--to quote his review "the leader of the Fada'iyan-e Islam" (p. 40). But if one looks at that page one sees that 
I only say that the group's views were "close to the positions" of the Ayatollah. Hardly the same thing.

Incredibly, the reviewer says that I overutilize newspapers, particularly the New York Times. But in the first three chapters, for example, there are 66 citations to archival documents and only 14 from newspapers. In almost every case, the newspaper is cited for either a direct quotation from a U.S. official or, as is clearly explained, to show what the media said--and what Americans heard--about Iran. The role of the media is one of the book's main themes. Even as superficial a reader as Mr. Rajaee could turn the pages of footnotes and see the falsehood of his statement.

Since Mr. Rajaee raises the' reason for the book's success and good reception, I might take the opportunity to point out that five years after its publication--and despite all the other books and personal memoirs that have been published concerning U.S.-Iran relations (including almost 50 documents of embassy materials published in Iran)-the book's analysis and account of events stands up virtually without error.

The real problem, of course, is that Mr. Rajaee knows nothing about the subject of U.S.-Iran relations and has never done any research on the subject. Is it too much to ask that reviewers have some qualification for dealing with the book under discussion? Perhaps they might also describe the author's main arguments and give the reader some sense of what is actually in the book.

\section{Barry Rubin}

[Barry Rubin is Senior Fellow at the Center for Strategic and International Studies, Georgetown University.] 